\title{
Worldbuilding Components and Transmedial Extensions of Computer Role-Playing Games*
}

\author{
Barbaros Bostan, Başak Tinli and Güven Çatak
}

\begin{abstract}
Video games borrow fictional worlds from other media or create their own unique worlds to spread to a wider audience but how these virtual worlds are created or what kind of components are used to build them are important questions that can be studied well with a systematic analysis of their content. It is also important to note here that once a fictional world is successful for one type of media, it usually expands through different media, which is defined as media narrative convergence or transmedia storytelling. This study attempts to find out the patterns and trends of worldbuilding methods in the fictional worlds of computer role-playing games. Adopting a systematic content analysis approach, 10 most successful computer roleplaying games are analyzed to identify their worldbuilding components and transmedial extensions. The analysis of video games includes information about the game world (world type, world map, distinct elements), points of interest and their corresponding map icons, species found in the fictional world (player species, flora, fungi, creatures, sentient species), information about culture (religion, language, government type, social organizations, the use of magic or technology). In this regard, repeating patterns of worldbuilding in games are presented and the framework that consists of three components (place, species, culture). The effects of each fictional world on different media are also given.
\end{abstract}

Keywords: Video games, fictional worlds, virtual worlds, worldbuilding, transmedia storytelling.

\footnotetext{
* Received: 14/10/2019 • Accepted: 31/01/2020

** Barbaros Bostan: Bahçeşehir University Faculty of Communication Department of Digital Game Design. Orcid id: 0000-0002-5572-8766, barbaros.bostan@comm.bau.edu.tr Başak Tinli: Bahçeşehir University Faculty of Communication Department of Digital Game Design. Orcid id: 0000-0001-9320-9169, basaktinli@gmail.com Güven Çatak: Bahçeşehir University Faculty of Communication Department of Digital Game Design. Orcid id: 0000-0002-4679-8973, guven.catak@comm.bau.edu.tr
} 


\title{
Bilgisayar Rol Yapma Oyunlarının Kurgusal Dünya Yaratma Bileşenleri ve Transmedya Uzantıları*
}

\author{
Barbaros Bostan, Başak Tinli ve Güven Çatak*
}

Öz

Bilgisayar oyunları diğer iletişim mecralarından kurgusal dünyalar ödünç alarak veya kendi eşsiz dünyalarını yaratarak daha geniş bir izleyici kitlesiyle buluşmayı hedefler ama bu sanal dünyaların nasıl yaratıldığı veya hangi bileşenler kullanılarak yaratıldığı soruları medya çalışmaları için cevabı verilmesi gereken sorulardır. Burada bir diğer önemli husus da bir medya türünde başarılı olan bir kurgusal dünyanın genelde diğer medya türlerine de geçiş yapmasıdır ve bu durum medya anlatı yakınsaması veya transmedya anlatı olarak isimlendirilmektedir. Bu çalışma bilgisayar rol yapma oyunlarının kurgusal dünyalarının yaratılmasındaki desenleri ve trendleri analiz etmeyi amaçlamaktadır. Sistematik içerik analizi yaklaşımı benimsenerek, 10 en başarılı bilgisayar rol yapma oyunu incelenmiş ve kurgusal dünya yaratma bileşenleri ile transmedya uzantıları tanımlanmıştır. İncelenen oyunlarda kurgusal dünya ile ilgili bilgiler (dünya tipi, dünya haritası, elementler), bu dünyaların ilgi çekici konumları ve bu konumların temsilleri, kurgusal dünyalarda bulunan türler (oynanabilir türler, bitki, mantar, hayvan, akıllı türler) ve kültürün kurgusal dünyalardaki bileşenleri (din, takvim, dil, para birimi, hükümet şekilleri, sosyal organizasyonlar, büyü veya teknoloji kullanımı) incelenmiştir. Bu bağlamda, incelenen oyunlarda tekrarlanan dünya yaratma yöntemleri sunulmuş ve kurgusal bir dünya yaratmak için mekân, tür ve kültür alt bileşenlerinden oluşan bir taslak ortaya çıkartılmıştır. Ayrıca her bir kurgusal dünyanın diğer medya türlerine ne şekilde yakınsadığı incelenmiştir.

Anahtar Sözcükler: Video oyunları, kurgusal dünyalar, sanal dünyalar, dünya yaratma süreci, transmedya anlatı.

\footnotetext{
* Geliş tarihi: 14/10/2019 • Kabul tarihi: 31/01/2020

** Barbaros Bostan: Bahçeşehir Üniversitesi İletişim Fakültesi Dijital Oyun Tasarımı Bölümü.

Orcid no: 0000-0002-5572-8766, barbaros.bostan@comm.bau.edu.tr

Başak Tinli: Bahçeşehir Üniversitesi İletişim Fakültesi Dijital Oyun Tasarımı Bölümü.

Orcid no: 0000-0001-9320-9169, basaktinli@gmail.com

Güven Çatak: Bahçeşehir Üniversitesi Illetişim Fakültesi Dijital Oyun Tasarımı Bölümü.

Orcid no: 0000-0002-4679-8973, guven.catak@comm.bau.edu.tr
} 


\section{Worldbuilding Components and Transmedial Extensions of Computer Role Playing Games}

Escalating popularity of video games are inviting players into remote fictional worlds more then ever before. With the development of communication technologies, games are becoming more engaging and immersive, giving the players the opportunity to explore exciting new worlds and enabling them to do the things they cannot do in the real world. Therefore the synthetic worlds of games are becoming an important aspect since millions of people are playing together in these cyberspaces (Castronova, 2008: 2).

Fictional worlds of games mostly spread to other media or share worlds originated in other types of media, so worldbuilding is everywhere with the transmedia use. The global entertainment industry is becoming increasingly world-based (Wolf, 2016: 30), and this change indicates the need for a new model of understanding for the design of fictional worlds, making game worlds and their transmedial nature an important area to study. Computer role-playing games in general are the genre where there are more player and game setting interaction taking place and typically role-playing games have more emphasis on worldbuilding. Therefore when a game is successful it is likely that the game world will be explored in other media, increasing its cultural influence.

Defining the elements of fictional world design can also create a better understanding of world building for the game industry and for the entertainment industry as a whole. Therefore, this study is concerned with the building blocks of fictional worlds. Analyzing the best examples from the game industry may ease the way for defining these components. By focusing on computer role-playing games, this study aims to reveal the trends and patterns in successful worldbuilding practices and to analyze their transmedial extensions.

\section{Recent Rise of Transmedia Projects}

In recent years, audiences are exposed to various kinds of media and it has become less likely for a story to stay within one type of media. The use of one type of medium and traditional adaptations has given rise to media convergence and transmedia 
projects. Stories are being told across multiple media and audiences experience not only single stories but also story-worlds. Henry Jenkins (2014:244) defines transmedia simply as "across media" and implies a structured or coordinated relationship among multiple media platforms and practices. However, the stories are not only rehearsed across media, but rather elaborated (Johnson, 2013). According to Tom Dowd (2015: 4), transmedia storytelling is more than just an adaptation of a story to different media but a process in which each expression tells a piece of a larger story. Jenkins (2006: 96) in his book Convergence Culture states that "Each medium does what it does best - so that a story might be introduced in a film, expanded through television, novels, and comics; its world might be explored through gameplay or experienced as an amusement park attraction". All these products are not just what they are solely but they act as gateways into transmedia worlds (Schell, 2019 337).

Stories, games, and events in a transmedia project share settings and characters that are building a fictional universe (Dena, 2009). According to Jenkins (2006: 21), transmedia storytelling is the art of worldmaking. A transmedia project is better equipped with an imaginary world or a fictional universe to feed all media platforms, with vast amounts of detail, such as backstories, mythology, history, and many characters. Lisbeth Klastrup and Susana Tosca (2004) define transmedia worlds as follows: "Transmedial worlds are abstract content systems from which a repertoire of fictional stories and characters can be actualized or derived across a variety of media forms." A transmedia world has to be rich and deep to be able to sustain the demands of different media. Jenkins (2003) points out to the need of world design for a successful transmedia franchise by saying: "A good character can sustain multiple narratives and thus lead to a successful movie franchise. A good 'world' can sustain multiple characters (and their stories) and thus successfully launch a transmedia franchise". This is why the character-oriented entertainment industry of the past is now focused on transmedia worlds.

The rise of transmedia worlds is substantially related to economic motives in the entertainment industry today. "Transactions such as Disney's purchase of the Star Wars franchise (along with George Lucas's companies) for just over $\$ 4$ billion, and Microsoft's purchase of Minecraft franchise (along with parent company Mojang) for \$2.5 billion, demonstrate the value that can be placed on a popular world" (Wolf, 2016: 
26). When a franchise is successful the companies behind want to make sure they make as much profit as they can from a storyworld and try to use all the media platforms, especially the new ones. "New forms of media rarely cannibalize older ones, but rather enhance them. Especially if you make them transmedia and they work together" (Zeiser, 2015: 7). So if a transmedia project is managed successfully, we can see different forms of media working together, embracing an imaginary world. Jenkins (2006: 16) points out the shift in the entertainment industry where in the past companies focused only on one media like film, such as Warner Bros, now produces film, television, popular music, video games, websites, toys, amusement park rides, books, newspapers, magazines, and comics.

Consumers are willing to invest in limited franchises choosing from variety of media options (Jenkins, 2003). "A transmedia narrative tells altogether one big pervasive story, attracting audience engagement" (Gambarato, 2013). And when there is an audience engaged with a particular storyworld, then it is more likely that the sales for products involving that storyworld will be higher compared to a newly created storyworld (Elkington, 2009: 232). Every new product will attract fans of that transmedia world and thus creating consumer loyalty has become the key focus of entertainment franchises. Melanie Bourdaa (2014) states that fans are the faithful and active audience who expand and spread the content on multiple media platforms; therefore transmedia strategies are focused on creating a fanbase for the franchise. Fans create more content, such as fan fiction and game mods or promote franchises on social media and forums, so that they become a part of the marketing process themselves.

\section{Video Games as Transmedia Projects}

Video games may be a late addition compared to other media, however, the game industry is already upstaging other media according to industry revenue. Each medium has its strengths and weaknesses, like novels are strong in creating inner voices and thoughts, while movies are better at conveying movement (Juul, 2011: 48). Games present a number of opportunities compared to more traditional media while choosing the right platforms for a transmedia project. Games are also played on different media platforms which makes them transmedial by form (Juul, 2011: 7). As examples, some card games are implementations and many sports games are adaptations (Juul, 2003). 
As media convergence has become the new trend, each media platform is borrowing elements from the others. Improvements in computer technologies have led to games being more narrative-oriented while film and television production has been relying on computer-generated imagery (CGI) more heavily (Elkington, 2009: 213). While the production processes are becoming more similar, first transmedia projects were more like cross-media adaptations or implementations. There are many games, which are just developed based on a television or film license. "Many publishers commission games to exploit a license: a particular intellectual property such as a book (The Lord of the Rings), movie (Die Hard), or sports trademark (NHL Hockey)" (Adams, 2014: 34). With a growing acceptance for games in culture, creating a new IP has become non-objectionable for games too and successful game IPs also turned into movie adaptations. But transmedia storytelling is not just an adaptation from one media to another (Scolari, 2009). Transmedia projects shine only when right media is chosen to engage the right audience. Early adaptations from games to movies were attempts, which resulted in failures according to their critic reviews, as transmedia use emphasizes elaborating a fictional world rather than retelling, enriching a game world while introducing it for new audiences is a hard to achieve task.

In the era of video games, players are able to create virtual identities, take on adventures and wander in new virtual worlds. With the use of transmedia game companies can also end up having income from novels or toys. And games serve as a great tool to create worlds and familiarize audiences with these worlds. Karin Fast and Henrik Örnebring (2017) states that "Many transmedia 'properties' have in fact grown organically over periods of several decades - and a transmedia world is not necessarily 'finished' when the 'original' creator dies". Since entertainment franchises are usually building IPs that are not the creation of one artist or author, many creators are working in the building of a fictional universe and with the use of multiple media ensuring the coherence of a fictional universe is a very challenging task. As an example, World of Warcraft is a fictional world which is a collaborated work of many writers and artists, when the need of a movie came into existence due to economic gains that can be achieved through millions of players, there have been many inconsistencies of the lore of the game setting in the movie which have angered fans of the game. One of the best examples of transmedia use in games is the Forgotten 
Realms game setting which has been created by Ed Greenwood (2001) as an official campaign setting for Dungeons and Dragons (D\&D). Though the setting is created originally for a tabletop role-playing game, the most successful computer role-playing games are also set in that world.

\section{Worldbuilding Practices}

Worldbuilding has become the center of attention in entertainment industry due to character-based franchises growing into world-based franchises. Worldbuilding is an important aspect of creative writing and many famous writers have started creating imaginary worlds in their childhood (Wolf, 2014: 15). In "On Fairy Stories”, John Ronald Reuel Tolkien (1947) introduces the terms "sub-creation", "secondary world" and "primary world". He states that "story-maker" becomes a "sub-creator" and creates a secondary world, which our minds can enter, and "primary world" is the world we are actually living in. Many fictional stories are set in the primary world, which contains the main social, geographical, and historical features of the actual world, although its population, and laws of nature, might differ (Ekman, 2013: 10). Secondary worlds are different than the primary world but according to Nelson Goodman (1978: 6) worldmaking as we know it always starts from worlds already on hand, the making is remaking and all other worlds are versions of the actual world. Therefore, when there are gaps in the design of a secondary world, the audience can assume those parts are similar to the primary world.

Immersion in a fictional world can be achieved through creating a consistent universe. "World building is the act of designing and constructing believable fictional universes." (Dowd, 2015: 21). To be believable, the backstory of a universe should be consistent. Tracy Fullerton (2014: 102) defines worldbuilding as "the deep and intricate design of a fictional world, often beginning with maps and histories, but potentially including complete cultural studies of inhabitants, languages, mythologies, governments, politics, economies, etc.". All of these elements of a world are a challenge to create therefore constructed worlds are not complete. Still, a sense of completeness can be achieved by creating a consistent logic of the fictional world. So to be able to create consistent history, geography, technology, culture, politics, religion, economy, sub-creators need to spend much time with the efforts of worldbuilding. 
Different sources on worldbuilding offer different methods and have different frameworks.

From all these different approaches it is easy to see that there are different methods on worldbuilding and each author has their preferred way of creating or understanding worlds. Also, worldbuilding for different media differs with their emphasis on world building components. For example, world building guides for roleplaying games have special sections just devoted to monsters or weapons and also geophysical indications about a world in these guides are rarely seen. However, all approaches are similar and cover nearly the same elements of worldbuilding. Elements of geography, history, and culture are almost always a concern for worldbuilding. Geography is the key component in creating a virtual environment; it is a building block, roots of a setting (Gygax and Cross, 2004: 64). History helps players in suspending disbelief by providing a realistic backdrop (Stypczynski, 2005). Cultures, languages, names, and philosophy all help the world to be feel more realistic and believable.

\section{Game Worlds and Computer Role-Playing Game Settings}

"All [play-grounds] are temporary worlds within the ordinary world, dedicated to the performance of an act apart" (Huizinga, 1949: 10). Therefore play is a way of building a world that is temporary "in which an absolute and peculiar order reigns" (Huizinga, 1949: 10). However this is a world of make-believe, and players leave their activities of reality and become performers in this new world. Ernest Adams (2014: 84) defines the game world as "an artificial universe, an imaginary place in which the events of the game occur. When the player enters the magic circle and pretends to be somewhere else, the game world is the place she pretends to be".

Not all game genres are the same and some game genres are better at conveying coherent worlds. "Role-playing games allow players to interact with a game world in a wider variety of ways than most other genres do, and to play a richer role than many games allow" (Adams, 2014: 453). Therefore, CRPGs shine when compared to other genres in terms of worldbuilding because they are the genre that focuses on story and exploration and since better worldbuilding opportunities in CRPGs also come with benefits of transmedia use, CRPGs are chosen to be the subject of this paper. Creating fictional worlds is an essential characteristic of RPGs (Baker, 2016:139). Dowd (2015: 
186) states that "table-top role-playing games are all about world building". RPG rulebooks like D\&D books are full of detail on fictional world infrastructures like races, places, characters, gods, religion, magic, equipment, flora, and fauna. Especially guides for game masters like Dungeon Master's Guide offers, "explicit coaching could itself be read as a type of conceptual infrastructure for world-builders" (Baker, 2016: 135).

When compared with other games RPGs require the player taking on the role of the game character more deeply and interacting with the game world as that character, this type of gameplay is much more slow-paced than of an action game and players have the time to explore and enjoy the game setting more. RPGs as a part of their nature require players to be more involved with the lore of the game setting. When a player takes on a role, this role is often shaped by the game world. The fictional world and its rules are the ones that limit the player activities. Tabletop RPGs have setting books that elaborate every aspect of these imaginary worlds so that the players can be free as they can be since role-playing games are based on leaving decision making to the player. CRPGs setting is an important factor, since one of the major gameplay modes of CRPGs is exploration (Adams, 2014: 459).

Creating a game setting for a RPG is different than creating a fictional world for other media. A game master should add all kinds of tools, dangers, hooks, conflicts in a game setting so that players have different interesting things to do (Baur, 2012: 9). For example, RPG books and supplements always have monster manuals or bestiaries to add enemies and conflicts. This is mostly the same with CRPGs; in some games players encounter more monsters and enemies than they meet with Non-Player Characters. Most RPG players like detail and with various kinds of characters, monsters, and places they have reasons to delve into the game worlds. World building for games does not have to be about the mechanics of the game it just needs vastness and reasons for conflict. As Wolfgang Baur (2012: 12) exemplifies most settings have been used for different games with different mechanics, like Star Wars or Forgotten Realms.

The methodology of this article is qualitative video game content analysis, a systematic analysis of selected video games with a special focus. Similar studies analyzed Nintento and Sega games with a focus on violence (Dietz, 1998), 60 popular 
console games with a focus on violent activity (Smith et al., 2003), and 130 games with a focus on cinematic representation techniques (Brand et al., 2003). The focus in this article is the worldbuilding components and CRPGs are chosen using the Metacritic website. ${ }^{1}$ Metacritic is a website, where games are listed according to their metascore, which is a weighted average of published critics. The site collects reviews from stable game sites and compiles the results into statistics based on a 100-point scale, with separate rankings for critic reviews which is metascore and fan reviews which is user score, resulting in a meta-review that gives a broad sense of what people are saying about a particular game. The games that have a metascore above 90 are universally acclaimed games. These games are likely to be familiar to the largest number of people due to their universal acclaim. The selected games are on personal computer (PC) platform and listed under the RPG genre. Furthermore, to eliminate potentially biased choices of games, the top ten games, which have the highest scores according to metascore, are selected. The list of selected games and their corresponding IDs used in the tables are given in the Table 1.

\begin{tabular}{|l|l|l|l|}
\hline ID & Game Name & Developer & Year \\
\hline G1 & Baldur's Gate II: Shadows of Amn & Bioware & 2000 \\
\hline G2 & The Elder Scrolls V: Skyrim & Bethesda Game Studios & 2011 \\
\hline G3 & Mass Effect 2 & Bioware & 2010 \\
\hline G4 & The Elder Scrolls IV: Oblivion & Bethesda Game Studios & 2006 \\
\hline G5 & Divinity: Original Sin Enhanced Edition & Larian Studios Games Ltd & 2015 \\
\hline G6 & Diablo & Blizzard Entertainment & 1996 \\
\hline G7 & The Witcher 3: Wild Hunt & CD Projekt Red Studio & 2015 \\
\hline G8 & Divinity: Original Sin II & Larian Studios Games Ltd & 2017 \\
\hline G9 & Star Wars: Knights of the Old Republic & Bioware & 2003 \\
\hline G10 & Undertale & Tobyfox & 2015 \\
\hline
\end{tabular}

Table 1: Game IDs used for selected games

\section{Game World}

Worlds can be defined with their relation to the primary world. The primary world is a template for fictional worlds. DeMaria and Perry (2014) divided the game worlds into

\footnotetext{
1 Metacritic-Movie Reviews, TV Reviews, Game Reviews, and Music Reviews. (n.d.).
} http://www.metacritic.com/ [accessed 10 March 2018]. 
different categories: our world, fantasy world, perspective world, futuristic world, sci-fi world, past world, historical world, period world, mythological-supernatural world, exploration of worlds and worlds based on fictional works.

The types of game worlds were separated according to David Perry's (DeMaria and Perry, 2014: 412) categorization of game worlds. While there were no other types out of his categorization, it is given in the Table 2 that many games had more than one world type. The most common world type was the fantasy world. Game world maps mostly consisted of regional maps of where the game takes place in that world and no game had a map of the whole fictional world. Sci-fi type of worlds had galaxy maps as an exception. Another important finding was about the physical elements that make up the game worlds, and out of ten games, eight games had unique distinct elements that are not found in the primal world.

\begin{tabular}{|c|c|c|c|}
\hline ID & World Type & World Map & Distinct Elements \\
\hline G1 & $\begin{array}{l}\text { Based on Fictional Work } \\
\text { Fantasy World }\end{array}$ & Regional Map & Illithium \\
\hline G2 & Fantasy World & Regional Map & Ebony \\
\hline G3 & $\begin{array}{l}\text { Sci-fi World } \\
\text { Futuristic World } \\
\text { Exploration of Worlds }\end{array}$ & Galaxy Map & Element Zero \\
\hline G4 & Fantasy World & Regional Map & Ebony \\
\hline G5 & Fantasy World & $\begin{array}{l}\text { Regional Map } \\
\text { Mini Map }\end{array}$ & Tenebrium \\
\hline G6 & Fantasy World & $x$ & $x$ \\
\hline G7 & $\begin{array}{l}\text { Based on Fictional Work } \\
\text { Fantasy World }\end{array}$ & $\begin{array}{l}\text { Regional Map } \\
\text { Mini Map }\end{array}$ & Dimeritium \\
\hline G8 & Fantasy World & $\begin{array}{l}\text { Regional Map } \\
\text { Mini Map }\end{array}$ & Tenebrium \\
\hline G9 & $\begin{array}{l}\text { Based on Fictional Work } \\
\text { Sci-fi World } \\
\text { Exploration of Worlds }\end{array}$ & $\begin{array}{l}\text { Galaxy Map } \\
\text { Mini Map }\end{array}$ & Cortosis \\
\hline G10 & Fantasy World & $x$ & $x$ \\
\hline
\end{tabular}

Table 2: Information about the game World

The games, which have regional world maps or galaxy maps, were also looked at to analyze what kinds of landmarks were used in game maps. Types of map icons that can be found in the maps of the game worlds are given in Table 3: Use of Map Icons in CRPGs. Baldur's Gate II: Shadows of Amn and Star Wars: Knights of the Old 
Republic use only text to mark places or planets. Mass Effect 2 also uses text to give the names of places that the player can go to while nebulas are marked with same icons on the Milky Way galaxy map. Divinity: Original Sin Enhanced Edition and Divinity: Original Sin II use the same kind of map icons and the icons that are used are simply markings of locations, waypoints, quests, and secrets. The Elder Scrolls V: Skyrim and The Elder Scrolls IV: Oblivion use more detailed icons to show landmarks like settlements, cities, caves, and forts. The Witcher 3: Wild Hunt has the most detailed list of map icons marking many different places of interest like hidden treasures, armorers, barbers, abandoned sites, harbors or herbalists.

\begin{tabular}{|c|c|c|}
\hline ID & Map Icon & Icon Description \\
\hline G1 & Names only No Icons & Landmark names are marked \\
\hline \multirow{11}{*}{ G2 } & ख & Cities have different icons \\
\hline & $\boldsymbol{\lambda}$ & Camp \\
\hline & A & Cave \\
\hline & $\geqslant 4$ & Clearing \\
\hline & 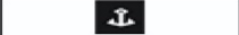 & Dock \\
\hline & $\theta$ & Standing Stone \\
\hline & $\mathbf{f}$ & Dragon Lair \\
\hline & $\mathbf{\theta}$ & Dwarven Ruin \\
\hline & 4 & Farm \\
\hline & $\boldsymbol{E}$ & Fort \\
\hline & $\mathrm{UU}$ & Giant Camp \\
\hline \multirow[t]{2}{*}{ G3 } & Names only No Icons & Planets and space stations \\
\hline & 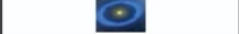 & Nebula \\
\hline \multirow{12}{*}{ G4 } & 理 & Ruins \\
\hline & $\mathbf{E}$ & Camp \\
\hline & n & Caves, Sewers \\
\hline & 6 & Cities, Gates, Districts \\
\hline & 27 & Shrine \\
\hline & 国 & Door \\
\hline & 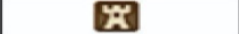 & Fort \\
\hline & S & Inns, Stables \\
\hline & m & Hills, Peaks, Places of Interest \\
\hline & 8 & Mine \\
\hline & (9) & Oblivion Gate \\
\hline & 28 & Small Settlement \\
\hline \multirow{5}{*}{ G5 } & (a) & Waypoint Shrines \\
\hline & 望 & Custom Marker \\
\hline & 2 & Location \\
\hline & 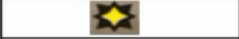 & Quest Marker \\
\hline & E्म & Secret \\
\hline
\end{tabular}

\begin{tabular}{|c|c|c|}
\hline ID & Map Icon & Icon Description \\
\hline \multirow{26}{*}{ G7 } & & Landmark names are marked \\
\hline & 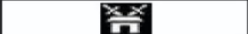 & Abandoned Site \\
\hline & 10 & Armorer \\
\hline & & Armorer Table \\
\hline & $\rightarrow=$ & Bandit Camp \\
\hline & & Barber \\
\hline & & Blacksmith \\
\hline & & Brothel \\
\hline & & Entrance \\
\hline & द & Grindstone \\
\hline & 8 & Guarded Treasure \\
\hline & 5 & Gwent Player \\
\hline & t? & Harbor \\
\hline & $\%$ & Herbalist \\
\hline & (5) & Hidden Treasure \\
\hline & c & Innkeep \\
\hline & & Monster Nest \\
\hline & & Monster Den \\
\hline & $\equiv$ & Notice Board \\
\hline & & Person in Distress \\
\hline & 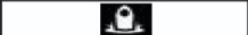 & Place of Power \\
\hline & & Point of Interest \\
\hline & & Sign Post \\
\hline & 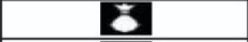 & Shopkeeper \\
\hline & 8 & Smugglers' Cache \\
\hline & $\frac{t}{t}$ & Spoils of War \\
\hline \multirow[t]{5}{*}{ G8 } & $\sqrt{5}$ & Quest Marker \\
\hline & P & Location \\
\hline & P & Custom Marker \\
\hline & te & Waypoint Shrines \\
\hline & 9 & Secret \\
\hline G9 & Names only No Icons & Planets \\
\hline
\end{tabular}

Table 3: Points of Interest, Map Icons in CRPGs

\section{Species}

Types of species that can be found in these game worlds were also analysed. Players can play as a human character in most of these games while Baldur's Gate II: Shadows of Amn, Divinity Series, and Elder Scrolls Series enabled players to play as different 
species. Fungi and flora were given importance in games with crafting mechanics that include alchemy skill, so these games included some distinct flora and fungi that are not from the primal world. Common flora and fungi from the primal world were also given magical properties in these games. Many NPCs belonged to different species in these games. While another important factor important in species in these worlds that it was hard to distinguish between sentient and non-sentient species since many of these come as enemy forces and attack the player without the opportunity to have a conversation with these creatures. Most fauna type creatures were given sentient attributes, for example, many creatures like dragons can speak or for example, in Divinity Series many animals and critters commonly found in the primal world can speak to the player character. Amount of distinctive species are given in Table 4.

\begin{tabular}{|c|c|c|c|c|c|}
\hline ID & $\begin{array}{l}\text { Player } \\
\text { Species }\end{array}$ & $\begin{array}{l}\text { Distinct } \\
\text { Flora }\end{array}$ & $\begin{array}{l}\text { Distinct } \\
\text { Fungi }\end{array}$ & $\begin{array}{c}\text { Distinct Fauna } \\
\& \text { Creatures }\end{array}$ & $\begin{array}{l}\text { Sentient } \\
\text { Species }\end{array}$ \\
\hline G1 & 7 & 4 & $x$ & 6 & 73 \\
\hline G2 & 10 & 12 & 6 & 25 & 19 \\
\hline G3 & 1 & $x$ & $x$ & 2 & 18 \\
\hline G4 & 10 & 7 & 3 & 3 & 19 \\
\hline G5 & 1 & 1 & $x$ & $x$ & 14 \\
\hline G6 & 1 & $x$ & $x$ & 4 & 12 \\
\hline G7 & 1 & 8 & $x$ & 14 & 45 \\
\hline G8 & 5 & 6 & 1 & 13 & 14 \\
\hline G9 & 1 & $x$ & $x$ & 21 & 19 \\
\hline G10 & 1 & $x$ & 1 & $x$ & 1 \\
\hline
\end{tabular}

Table 4: Species Found in CRPGs

\section{Culture}

The culture in a game setting can be diverse and can include many layers. The existence of different languages, religions, economies, politics, magic and technology from the actual world were questioned. In every game, information about the history of the world could be found. However, not all games had timelines and sense of time as when the events in the game are taking place cannot be found in all games since the years are not told in each game. Only in Elder Scrolls games, the player knows the exact date in time and the game world has a distinct calendar system with different month and day names. In Baldur's Gate II: Shadows of Amn, The Witcher 3: Wild 
Hunt, Undertale and Star Wars: Knights of the Old Republic players can vaguely understand when the game takes place in that world's history, and distinct calendar systems are only mentioned. Divinity Series and Diablo did not have any dates while the history of these fictional worlds was given in these games without a calendar. Mass Effect 2 was an exception since the game was using the primal world calendar in a future time and had a timeline in the game codex.

The languages that can be found in the fictional worlds of these games were mentioned or could be heard with a few lines talked by NPCs in games. Diablo and Undertale did not mention any different languages. Religion took an important part in these games with the exception of Star Wars and Undertale where no religion was mentioned. Most of the games had multiple gods pointing at Polytheism. Many religious cults and religious figures as NPC characters could be found in these games along with many religious buildings such as churches, shrines, altars and temples. Mass Effect as a fictional world, taking place in the future of the primal world mentioned primal world religions and also had codex entries for alien species' religious beliefs. All fantasy worlds used gold as the currency with the exception of The Witcher 3: Wild Hunt where crowns were used as main currency. Sci-fi type of worlds used credits as the main currency.

Data gathered from these game worlds in terms of political information was hard to distinguish. Apart from Mass Effect 2 where types of the political rule were given with game codex entries, all games had only political figures mentioned or included as NPCs. According to these political figures aristocracy, monarch and empires were mostly seen as forms of government. In all fantasy types of worlds, magic existed while in sci-fi type of worlds technology took its place. Undertale mentions both distinct technology and magic as an exception. Cultural information gathered from the video games are given in Table 5.

\begin{tabular}{|c|c|c|c|c|}
\hline ID & Religion & Currency & Forms of Government & $\begin{array}{c}\text { Magic or } \\
\text { Technology }\end{array}$ \\
\hline G1 & Polytheism & Gold & $\begin{array}{c}\text { Aristocracy, Empire, } \\
\text { Monarchy, Tribalism, City } \\
\text { State }\end{array}$ & Magic \\
\hline G2 & Polytheism & Gold & $\begin{array}{c}\text { Aristocracy, Empire, } \\
\text { Monarchy }\end{array}$ & Magic \\
\hline
\end{tabular}




\begin{tabular}{|c|c|c|c|c|}
\hline G3 & $\begin{array}{c}\text { Primal World } \\
\text { Religions, } \\
\text { Monotheism, } \\
\text { Ancestor Worship }\end{array}$ & Credit & $\begin{array}{c}\text { Aristocracy, Republic, } \\
\text { Meritocracy, Autocracy }\end{array}$ & Technology \\
\hline G4 & Polytheism & Gold & $\begin{array}{c}\text { Aristocracy, Empire, } \\
\text { Monarchy }\end{array}$ & Magic \\
\hline G5 & Polytheism & Gold & $\begin{array}{c}\text { Aristocracy, Tyranny, } \\
\text { Monarchy }\end{array}$ & Magic \\
\hline G6 & Religious Cults & Gold & Monarchy & Magic \\
\hline G7 & $\begin{array}{c}\text { Polytheism, } \\
\text { Religious Cults }\end{array}$ & $\begin{array}{c}\text { Floren, } \\
\text { Oren }\end{array}$ & $\begin{array}{c}\text { Aristocracy, Empire, } \\
\text { Monarchy, Theocracy }\end{array}$ & Magic \\
\hline G8 & Polytheism & Gold & $\begin{array}{c}\text { Aristocracy, Tyranny, } \\
\text { Monarchy }\end{array}$ & Magic \\
\hline G9 & $\mathbf{x}$ & Credit & $\begin{array}{c}\text { Empire, Republic, Tribalism, } \\
\text { Martial Law }\end{array}$ & Technology \\
\hline G10 & Gold & Monarchy & $\begin{array}{c}\text { Magic and } \\
\text { Technology }\end{array}$ \\
\hline
\end{tabular}

Table 5: Information about Culture

Another important cultural finding in these games was that every game world included social organizations. Various social organizations included mostly military organizations, religious cults, guilds, and mercenary bands. Elder Scrolls Series, which had the broadest range of social organizations, has guilds, religious cults, military and intelligence organizations, monastic orders, economical and political organizations to different groups for magic users.

\section{Transmedia Use in Games}

Worldbuilding components are required for any type of worldbuilding in any media. However, as discussed in the previous chapter traits like transmediality are not required for creating fictional worlds but it is an increasing trend and many games and movies are adopting transmedia use. Themes like these should not be overlooked while looking at worldbuilding in CRPGs. These themes together with the worldbuilding components will create solid ground towards the drawing of further conclusions and the final attempt of categorizing worldbuilding in CRPGs.

Data collected about the transmediality and uses of different kinds of media related to a game world are given in Table 6: Transmediality and types of different media. Seven out of ten fictional worlds are originated in video games. Most of the games use many different media and novels, comics, graphic novels, and analog 
games were the mostly used media. Only sci-fi type of worlds had amusement park attractions. Divinity games and Undertale were exceptions since their worlds did not spread into different media.

\begin{tabular}{|c|c|c|c|c|c|c|c|c|c|}
\hline & $\begin{array}{l}\text { Origin } \\
\text { Media }\end{array}$ & $\begin{array}{l}\text { Novels/ } \\
\text { Short } \\
\text { Stories }\end{array}$ & $\begin{array}{l}\text { Graphic/ } \\
\text { Interactive } \\
\text { Novels }\end{array}$ & Comics & $\begin{array}{l}\text { Amusement } \\
\text { Park } \\
\text { Attractions }\end{array}$ & Film & $\begin{array}{l}\text { Analog } \\
\text { Games }\end{array}$ & $\begin{array}{l}\text { Tv } \\
\text { Shows }\end{array}$ & $\begin{array}{l}\text { Other } \\
\text { Media }\end{array}$ \\
\hline $\begin{array}{l}\text { Baldur's } \\
\text { Gate II: } \\
\text { Shadows } \\
\text { of Amn }\end{array}$ & $\begin{array}{l}\text { Magazine } \\
\text { Articles }\end{array}$ & & & $\checkmark$ & $\mathbf{x}$ & $x$ & $\checkmark$ & $x$ & $x$ \\
\hline $\begin{array}{l}\text { The Elder } \\
\text { Scrolls V: } \\
\text { Skyrim }\end{array}$ & $\begin{array}{l}\text { Video } \\
\text { Game }\end{array}$ & $r$ & $x$ & 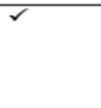 & $x$ & $x$ & $\sqrt{2}$ & $x$ & $x$ \\
\hline $\begin{array}{l}\text { Mass } \\
\text { Effect } 2\end{array}$ & $\begin{array}{l}\text { Video } \\
\text { Game }\end{array}$ & 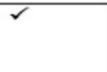 & 2 & r & 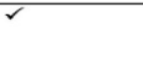 & 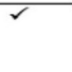 & 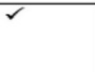 & $x$ & Application \\
\hline $\begin{array}{l}\text { The Elder } \\
\text { Scrolls } \\
\text { IV: } \\
\text { Oblivion }\end{array}$ & $\begin{array}{l}\text { Video } \\
\text { Game }\end{array}$ & $r$ & $x$ & $r$ & $x$ & & $r$ & $x$ & $x$ \\
\hline $\begin{array}{l}\text { Divinity: } \\
\text { Original } \\
\text { Sin } \\
\text { Enhanced } \\
\text { Edition }\end{array}$ & $\begin{array}{l}\text { Video } \\
\text { Game }\end{array}$ & $x$ & $x$ & $x$ & $x$ & $x$ & $x$ & $x$ & $x$ \\
\hline Diablo & $\begin{array}{l}\text { Video } \\
\text { Game }\end{array}$ & $r$ & $r$ & $r$ & $x$ & $x$ & $r$ & $x$ & $x$ \\
\hline $\begin{array}{l}\text { The } \\
\text { Witcher 3: } \\
\text { Wild Hunt }\end{array}$ & $\begin{array}{l}\text { Short } \\
\text { Stories }\end{array}$ & 2 & $r$ & 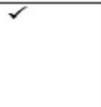 & $x$ & 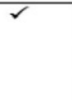 & $\bar{r}$ & $\bar{r}$ & $x$ \\
\hline $\begin{array}{l}\text { Divinity: } \\
\text { Original } \\
\text { Sin II }\end{array}$ & $\begin{array}{l}\text { Video } \\
\text { Game }\end{array}$ & $x$ & $x$ & $x$ & $x$ & $x$ & $x$ & $x$ & $x$ \\
\hline $\begin{array}{l}\text { Star Wars: } \\
\text { Knights of } \\
\text { the Old } \\
\text { Republic }\end{array}$ & Film & $r$ & $r$ & $r$ & $r$ & $r$ & $r$ & $\checkmark$ & $\begin{array}{l}\text { Application, } \\
\text { Audio } \\
\text { Drama, } \\
\text { Animation }\end{array}$ \\
\hline Undertale & $\begin{array}{l}\text { Video } \\
\text { Game }\end{array}$ & $x$ & $x$ & $x$ & $x$ & $x$ & $x$ & $x$ & $x$ \\
\hline
\end{tabular}

Table 6: Transmediality and types of different media

\section{Conclusion}

The games analysed for this study are role-playing games and like other role-playing games they provide very detailed and interactive virtual worlds, which aim to look and feel alive. This aim is achieved by placing different player races, distinct flora and fungi, and sentient creatures into a world divided by regions or galaxies. Almost each game uses a distinct element, which has different properties than the elements or materials of the real world and is usually used for crafting items for the player. Fictional worlds are usually differentiated from the real world by either magic or technology, depending 
on the theme of the game. The believability of the fictional worlds are increased with cultural aspects like religions, governments and social organizations which are again shaped according to the theme and story of the game. One of the most interesting findings of this study is that 7 of the 10 video games started their media journey as a video game and four of them have transmedial extensions such as novels/short novels, graphic/interactive novels, comics, physical games and even movies. This contradicts with the common misconception that successful games are usually adaptations of other media, such as novels and movies. Findings show that video games can also build believable and rich fictional worlds, which are later adapted to other media.

All things considered, by organizing the worldbuilding components (as seen in Figure 1) with an attempt to categorize fictional worlds in CRPGs, this study tried to unearth the hidden patterns that appeared in successful CRPGs. As given in previous sections, worldbuilding in games does not have a mathematical formula and fictional worlds can be vast and approaching them to require a study in depth, so that this study may just be top of an iceberg in terms of worldbuilding studies. Based on the material presented in the analytical section only some aspects of worldbuilding were shed into the light and this can lead to new types of analysis for future game research on worldbuilding.

This study showcases the similarities between the fictional worlds of successful CRPGs. When the findings on the information sources are analyzed it can be seen that CRPGs use similar sources as cut-scenes, graphics interface, in-game text, NPC conversations. Codexes or glossaries where lots of information can be given about game lore were rare, only available in two of the games. The information about the types of game worlds also shows that most CRPGs use fantasy worlds as a base for their fictional worlds and only two of the games had sci-fi worlds. This led to the use of magic or technology according to the type of world. There were no fictional worlds without magic or science fiction technology. Similar patterns in cultural elements such as religion, economic currency, and forms of government can also be seen from the data gathered. In all games, existence of social organizations was observed. 


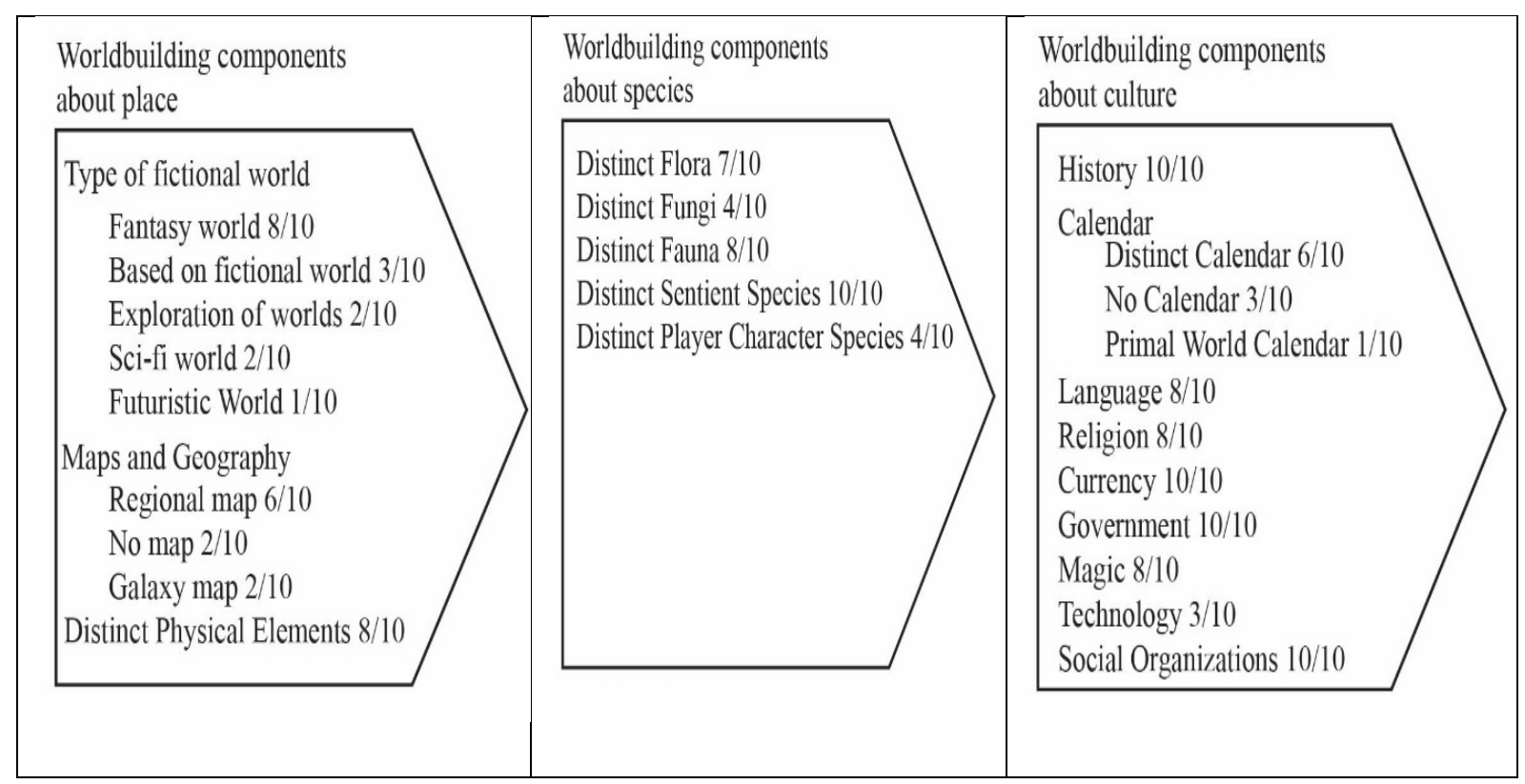

Figure 1: Worldbuilding components found in CRPGs

Species were another topic where the data gathered showcased similar patterns in CRPGs. Games had many sentient and non-sentient species especially functioning as enemies, creatures, and NPCs. Different fungi and flora species were especially seen in games with detailed crafting systems such as alchemy.

For the use of transmedia, it can be seen that most of the game worlds can be seen as expanded in different media, this pattern could not be observed in all the chosen CRPGS. The applicability of this research may be limited by its method and sample since only a handful of CRPGs were examined, but it is still important in a variety of ways. For example, video games are becoming a mature medium every year and a game world can spread to different media. This study showed that most of the fictional worlds analyzed were originated as video games and spread to different media and therefore they are affecting our culture even more. The different media that were used by these franchises are listed in Figure 2. 


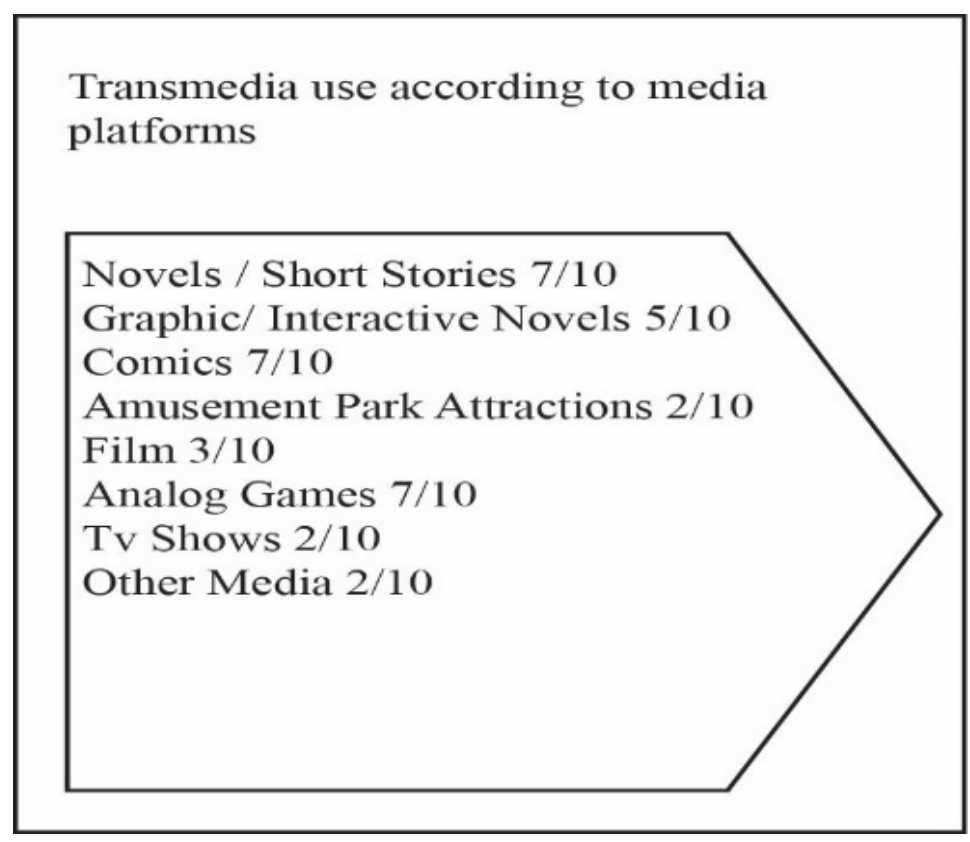

Figure 2: Usage of Different Media Platforms

The repetition of themes that emerge in same type of worlds like sci-fi and fantasy worlds as shown with the data gathered can be an indication of the lack of attention on design elements. To help the artistic vision and creativity that is needed for future fictional worlds, and for staying away from overused setting and themes, looking at patterns of worldbuilding in video games could be necessary. Other fictional world types can be used or can even be added to the list of world types by looking at the nature of the game worlds that already exist. This study showcases the elements of the overused themes but more research is needed to understand the reasons behind the decisions of the designers. Designers and artists' creativity are not the only factor when we are talking about games that are created with a budget and a deadline at hand. Worldbuilding is also mostly related to game writing and limits of game production create many obstacles for game writers as well as designers and artists. Examples from the findings such as repetition of elements like gold for coinage, fantasy worlds stereotyped as monarchies with polytheist cultures can also mean that game production has not yet shown enough effort for making extensive research for game writing. On the other hand, simplifying game worlds by using medieval or futuristic game settings has been a method in games, and is even advised for game designers to streamline their storytelling practices (Schell, 2019 306). 
Another interesting field, this study could open is that investigating the areas in the primal world that are not paid most attention in video games up until now can lead to new world design or game design approaches. The elements that are seen in this study are also pointing to the new areas in the primal world that can be explored by game and world design. Creating more diverse worlds for video games can become possible with the help of these kinds of research. 


\section{References}

Adams, Ernest (2014). Fundamentals of Game Design. San Francisco, CA: New Riders.

Baker, Neal (2016). "Secondary World Infrastructures and Tabletop Fantasy RolePlaying Games." In Revisiting Imaginary Worlds: A Subcreation Studies Anthology. Mark J. P. Wolf (eds.). New York: Routledge. 113-125.

Baur, Wolfgang (2012). "What Is Setting Design." In The KOBOLD Guide to Worldbuilding. Janna Silverstein. Kirkland: Open Design LLC. 8-12.

Brand, Jeffrey E., Scott Knight and Jakub Majewski (2003, November). "The Diverse Worlds of Computer Games: A Content Analysis of Spaces, Populations, Styles and Narratives." In DiGRA Conference.

Bourdaa, Melanie (2014). "This is Not Marketing. This is HBO: Branding HBO with Transmedia Storytelling." Networking Knowledge: Journal of The MeCCSA Postgraduate Network, 7(1): 18-25.

Castronova, Edward (2008). Synthetic Worlds: The Business and Culture of Online Games. London: University of Chicago Press.

DeMaria, Rusel and David Perry (2014). David Perry On Game Design: A Brainstorming Toolbox. Boston, MA: Cengage Learning.

Dena, Christy (2009). "Transmedia Practice: Theorising the Practice of Expressing a Fictional World Across Distinct Media and Environments." Doctoral dissertation, University of Sydney.

Dietz, Tracy L. (1998). "An Examination of Violence and Gender Role Portrayals in Video Games: Implications for Gender Socialization and Aggressive Behavior." Sex Roles, 38(5-6): 425-442.

Dowd, Tom (2015). Storytelling Across Worlds: Transmedia for Creatives and Producers. New York and London: Focal Press.

Ekman, Stefan (2013). Here Be Dragons: Exploring Fantasy Maps and Settings. Middletown, Connecticut: Wesleyan University Press.

Elkington, Trevor (2008). "Too Many Cooks: Media Convergence and Self-defeating Adaptations." In The Video Game Theory Reader 2. New York: Routledge. 235258. 
Fast, Karin and Henrik Örnebring (2017). "Transmedia World-Building: The Shadow (1931-present) and Transformers (1984-present)." International Journal of Cultural Studies, 20(6): 636-652.

Fullerton, Tracy (2018). Game Design Workshop: A Playcentric Approach to Creating Innovative Games. New York: Crc Press.

Gambarato, Renira Rampazzo (2013). "Transmedia Project Design: Theoretical and Analytical Considerations." Baltic Screen Media Review, 1(1): 80-100.

Goodman, Nelson (1978). Ways of Worldmaking (Vol. 51). Indianapolis, Indiana: Hackett Publishing.

Greenwood, Ed (2001). Forgotten Realms: Dungeons \& Dragons Campaign Setting. Renton, WA: Wizards of the Coast.

Gygax, Gary and Dan Cross (2004). Gary Gygax's World Builder. Arkansan, USA: Troll Lord Games.

Huizinga, Johan (1949) Homo Ludens: A Study of The Play Elementlin Culture. 3rd edn. London: Routledge \& Kegan Paul.

Jenkins, Henry (2003). "Transmedia Storytelling: Moving Characters from Books to Films to Video Games Can Make Them Stronger and More Compelling." www.technologyreview.com. Access date: 20.08.2019.

Jenkins, Henry (2006). Convergence Culture: Where Old and New Media Collide. New York and London: NYU press.

Jenkins, Henry (2014). “The Reign of the 'Mothership': Transmedia's Past, Present, And Possible Futures." Wired TV: Laboring Over an Interactive Future. Denise Mann (eds.). London: Rutgers University Press. 244-268.

Johnson, Derek (2013). "A History of Transmedia Entertainment." www.spreadablemedia.org. Access date: 02.09.2019.

Juul, Jesper (2003). "The Game, The Player, The World: Looking for A Heart of Gameness." In Level Up: Digital Games Research Conference Proceedings. 4-6 November 2003.

Juul, Jesper (2011). Half-real: Video Games Between Real Rules and Fictional Worlds. London: MIT press. 
Klastrup, Lisbeth and Susana Tosca (2004, November). "Transmedial WorldsRethinking Cyberworld Design". In 2004 International Conference on Cyberworlds. IEEE. 409-416.

Metacritic - Movie Reviews, TV Reviews, Game Reviews, and Music Reviews. (n.d.). http://www.metacritic.com/. Access date: 10 March 2018.

Schell, Jesse (2019). The Art of Game Design: A Book of Lenses. New York: CRC Press.

Scolari, Carlos Alberto (2009). "Transmedia Storytelling: Implicit Consumers, Narrative Worlds, and Branding in Contemporary Media Production." International Journal of Communication, 3: 586-606.

Smith, Stacy L., Ken Lachlan and Ron Tamborini (2003). "Popular Video Games: Quantifying the Presentation of Violence and Its Context." Journal of Broadcasting \& Electronic Media, 47(1): 58-76.

Stypczynski, Brent (2005). "No Roads Lead to Rome: Alternate History and Secondary Worlds." Extrapolation, 46(4): 453-468.

Tolkien, John Ronald Reuel (1947). On Fairy-stories. Oxford: Oxford University Press. Wolf, Mark J. (2014). Building Imaginary Worlds: The Theory and History of Subcreation. Routledge.

Wolf, Mark J.P. (2016). Revisiting Imaginary Worlds: A Subcreation Studies Anthology. New York: Routledge. https://www.routledge.com/Revisiting-Imaginary-WorldsA-Subcreation-Studies-Anthology/Wolf/p/book/9781138942059. Access date: 05.08.2019.

Zeiser, Anne (2015). Transmedia Platforms: A Creator's Guide to Media and Entertainment. New York: CRC Press. 